ENTREPRENEURSHIP AND SUSTAINABILITY ISSUES

ISSN 2345-0282 (online) http://jssidoi.org/jesi/

2021 Volume 9 Number 2 (December)

http://doi.org/10.9770/jesi.2021.9.2(16)

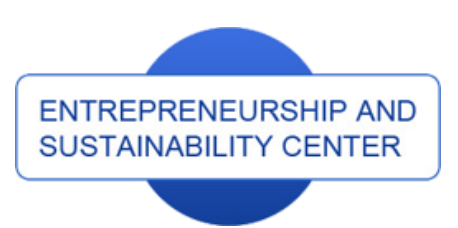

Publisher

$\underline{\text { http://jssidoi.org/esc/home }}$
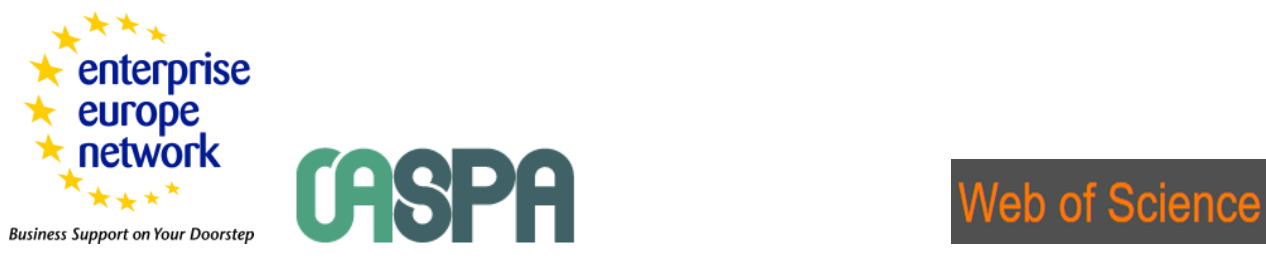

Clarivate
Analytics

\title{
COMPANY LIQUIDITY AS A REFLECTION OF RECEIVABLES AND PAYABLES MANAGEMENT*
}

\author{
Nora Štangová ${ }^{1}$, Agneša Víghová ${ }^{2}$ \\ ${ }^{1}$ University of Economics and Management of Public Administration in Bratislava, Department of Small and Medium \\ Business, Furdekova 16, 85104 Bratislava 5, Slovakia \\ 2 University of Economics and Management of Public Administration in Bratislava, Department of Small and \\ Medium Business, Furdekova 16, 85104 Bratislava 5, Slovakia \\ E-mails: ${ }^{1}$ nora.stangova@vsemvs.sk; ${ }^{2}$ agnesa.vighova@vsemvs.sk
}

Received 25 August 2021; accepted 29 October 2021; published 30 December 2021

\begin{abstract}
A reliable statement of a company's financial position can be obtained by analyzing its ability to pay its liabilities. A financially stable company can pay its liabilities, and a company in financial difficulties has problems with this. For these reasons, it is important to keep the company's liquidity at an optimal level. The article aims to point out liquidity in the context of the image of receivables and liabilities management through the research method of analysis and comparison. The analysis was performed on the basis of the balance sheet of the selected company, where the asset structures were analyzed. We drew our attention to the receivables and liabilities of the analyzed company. We presented the results of the analysis in the final part of the article.
\end{abstract}

Keywords: transformation process; receivables; liabilities; liquidity ratios; management of receivables and liabilities

Reference to this paper should be made as follows: Štangová, N., Víghová, A. 2021. Company liquidity as a reflection of receivables and payables management. Entrepreneurship and Sustainability Issues, 9(2), 238-254. http://doi.org/10.9770/jesi.2021.9.2(16)

JEL Classifications: H83

\footnotetext{
* The paper is the output of a scientific project IGA no. 1/2021 "Modernizing the Business Areas in European Countries in the Current Challenges with the Aim of Ensure Sustainable Economic Growth” (Funder: VSEMvs IGA VSEMvs, i.e. School of Economics and Management in Public Administration).
} 


\section{ENTREPRENEURSHIP AND SUSTAINABILITY ISSUES}

ISSN 2345-0282 (online) http://jssidoi.org/jesi/

2021 Volume 9 Number 2 (December)

http://doi.org/10.9770/jesi.2021.9.2(16)

\section{Introduction}

Effective management of receivables and payables in companies is extremely important in every entity, as they are also linked to financial indicators such as liquidity, solvency, and indebtedness. A high level of receivables can cause an entity to become secondary insolvency, which can lead to an increase in liabilities and ultimately the inability to repay them. Each entity should monitor, in addition to liquidity, the ratio of own funds to liabilities. If foreign resources exceed own funds, it means a high indebtedness for the entity, which is an undesirable situation for the company as well as for the company's surroundings. The aim of companies should be to manage receivables and payables and achieve their declining state.

\section{Literature review}

Receivables and payables are an important part of the financial statements within the balance sheet. The time structure of receivables and payables is also important, ie whether they are long-term or short-term receivables and payables. The high level of receivables for the entity represents the risk that it will not have the necessary amount of cash available to pay due liabilities. A high level of liabilities is also a negative phenomenon for the entity, as it threatens the financial stability of the company. These and other findings are presented by the authors in their publications: Alex, 2005; Farkaš, 2020; Jenčová \& Rákoš, 2010; Štangová et al., 2012; Kieso \& Weygandt, 2007; Šuranová \& Škoda, 2007; Stewart \& Connolly, 2021; Sacer \& Zyznarska-Dworczak, 2020; Henrique et al. 2020; Bernstein \& Wild, 1999; Hellmann \& Patel, 2021; Tawiah \& Gyapong, 2021.

Receivables and payables form the basis for calculating liquidity. Liquidity is divided into three levels: liquidity of the 1st, 2nd, and 3rd degree. The resulting values of these indicators predict the current solvency of the company. The following information is provided by the authors: Zalai, 2016; Miah, 2021; Jakubec \& Kardoš, 2016; Roca, 2021; Oreský \& Rehák 2019; Vlachynský et al., 2009; Wijekoon et al., 2021; Fabus, 2015; Lombardi, et al., 2020; Kajanová, 2014; Mládek, 2005; Miah et al., 2021, Štangová \& Hajduchová, 2010; Savina et al., 2021; Kajanová et al., 2014.

Management of receivables and payables for the company means the financial health of the company, which will ensure the long-term operation of the company. The authors wrote about this idea in their publications: Daniel, 2013; Frintrup, et al., 2020; Gernon \& Meek, 2001; Horváthová et al., 2016; Hillebrandt, M. \& Leino-Sandberg, 2021; Kainth \& Wahlstrom, 2021; Kotulič et al., 2018; Majduchová \& Neumannová, 2008; Tumpach, 2006; Majduchova et al., 2020; Pavic, 2020; Riahi-Belkaoui, 2000; Šlosárová \& Blahušiaková, 2020; Suhányiová \& Fabian, 2010; Suhányiová, et al., 2016; Suhányiová, 2009; Suhányiová, 2011; Silva et al 2021a, $2021 b$.

\section{The transformation process in the organization}

In the transformation process of a company, production factors are combined and transformed as inputs into different types of outputs, i.e. products and services. To obtain the required outputs, the company carries out various activities (Majduchová et al., 2020; Natalizi, 2020).

The business transformation process is the process of transforming inputs into outputs, within which a measurable value is created in the form of products or services (Oreský \& Rehák, 2019). This value arises through the individual activities that the company must provide.

There are two basic approaches to the transformation process, which are based on the above definition: 
a / creation of measurable value - the basis is considered the process of conversion of individual inputs into finished outputs. This approach illustrates Gutenberg's model of the transformation process - it is the implementation of business activities - that ensure the transformation process and which are expressed in Porter's model of the transformation process (Table 1).

Table 1. Gutenberg model of transformational process

\begin{tabular}{|c|c|c|}
\hline \multicolumn{2}{|c|}{ Financial outputs } & Financial sphere \\
\hline $\begin{array}{c}\text { Raw materials, materials, semi-finished } \\
\text { products, machines, equipment, } \\
\text { technologies, employees (company } \\
\text { property and human resources) }\end{array}$ & $\begin{array}{c}\text { Finished but unrealized products } \\
\text { (previously unfinished but work in } \\
\text { progress) }\end{array}$ & Performance results (realized products) \\
\hline \multicolumn{2}{|c|}{$\begin{array}{c}\text { PROCUREMENT } \\
\text { Source: Majduchová \& Neumannová (2008) } \\
\text { Material and commodity sphere }\end{array}$} \\
\hline
\end{tabular}

b / creation of monetary value. The monetary side of the transformation process is ensured by the company's finances, which form a system of monetary relationships, which the company enters into obtaining financial resources, placing and tying them in individual components of assets, productive use of assets, and distribution of results. Flow quantities are revenues and costs, as well as monetary income and expenses (Suhányiová, 2011).

\subsection{Analytical view of the company's assets}

The exact definition of property is determined by Act no. 431/2002 Coll. on accounting: Assets are the assets of an entity that are resulting from past events, it is almost certain that they will increase the economic benefits of the entity in the future, they can be measured reliably, and are recognized in the financial statements in the balance sheet, or statement of assets and liabilities. In terms of time, the assets are divided into:

- long-term asset,

- current assets.

When reporting assets in the balance sheet, it is theoretically possible to apply two approaches:

- the purpose of the acquisition of the assets is taken into account: the purpose expresses the relationship to the operating cycle,

- assets are ranked according to liquidity: liquidity is determined by the time required to convert assets into cash.

It is an asset that is divided from the most liquid assets to less liquid assets or, conversely, from the least liquid assets to the most liquid assets (Kajanová, 2014). 


\section{ENTREPRENEURSHIP AND SUSTAINABILITY ISSUES}

ISSN 2345-0282 (online) http://jssidoi.org/jesi/

2021 Volume 9 Number 2 (December)

http://doi.org/10.9770/jesi.2021.9.2(16)

It is characteristic of double-entry bookkeeping that not only the assets are monitored, but also the origin of the assets, i.e. from which the accounting entity acquired individual parts of the assets, from which sources it financed them. Sources of coverage are called liabilities in accounting, they are part of the balance sheet. Liabilities are sources of assets, which represent the total amount of own and external sources of assets, are accounted for in account class 4 - Equity and long-term liabilities, account class 2 - Short-term financial liabilities, and account class 3 - Other short-term liabilities other than financial liabilities.

Foreign sources of asset coverage are referred to as liabilities.

\subsection{Accounting relationships, a brief analysis of receivables and payables, liquidity}

A receivable and a liability represent one business transaction between two parties to a relationship. The creation of one party to a business relationship is always associated with the creation of an obligation with the other party to a business relationship. When accounting and reporting receivables and payables, it is important to respect the principle of non-compensation (Farkaš, 2020). This means that if a receivable arises in an entity, it must be accounted for as a receivable at the time it arises. If a subsequent entity incurs a liability in the same context, it shall be recognized as a liability, not as a reduction in the receivable. The proof of accounting for receivables and payables is the documents proving their origin.

\section{1/ Receivables}

Receivables arise whenever there is a time mismatch between the occurrence of a particular business operation and the time of payment. From this point of view, receivables have many advantages, but also disadvantages.

The basic advantages of receivables include:

- a payment condition which is part of the commercial offer and marketing measures to promote sales,

- the length of the deferment of payment can become one of the essential elements of competitive advantage in the fight for market share.

The basic disadvantages of receivables include:

- there is always a risk of non-payment,

- a business loan must be financed by the company in some way, which means an increase in financial costs for it.

A company needs to manage receivables and payables.

The key issues of receivables management are:

- minimization of the time between the origin and payment of the receivable,

- minimizing the risk that the receivable will not be repaid by the debtor.

The management of receivables in the company takes place on two levels, namely prevention and enforcement. The task of prevention is to ensure that in the future there is no irretrievable, resp. late receivables. Recovery takes place in the case of an outstanding receivable.

\section{2 / Liabilities}

They represent an entity's existing obligation arising from past events, they are likely to reduce the entity's economic benefits in the future and can be measured reliably, they are recognized in the financial statements in the balance sheet, or in the statement of assets and liabilities. 
The liability is the settlement relationship from the debtor's point of view. It is the debtor's obligation to fulfill his obligation to the creditor. The obligation expires, when it is settled by the debtors. It arises as a result of a transaction, can be valued (expressed in monetary units), and should lead to an outflow of funds.

\section{3 / Liquidity and the need for its management}

Liquidity means the current solvency of a company to pay its due liabilities and is a measure of immediate solvency.

Solvency means the current ability to settle liabilities. If the company is permanently illiquid (financial balance is disturbed, we speak of insolvency).

The basis of liquidity is the mutual relationship between the components of current (short-term) assets and shortterm liabilities and in the financial sense. An enterprise is liquid when, at a particular date, it has sufficient funds to settle its payables. However, this seemingly simple statement has several problems:

1. the first problem concerns the time period,

2. the second problem is the correct interpretation of the expression "having at its disposal".

3. the third problem is related to the maturity of liabilities.

Liquidity means the conversion of funds. Substantially all of a company's assets, both non-current and current, can be converted into cash. (Kotulič et al., 2018). The conversion time varies from asset to asset. Receivables, resp. short-term assets are transformed into money faster, while long-term assets have a longer time of transformation into cash. The easier it is to transfer assets to money, the more liquid it is. However, there is also a risk that some types of assets will never be converted into money. We understand it as a measure of a property's ability to transform.

\subsection{Liquidity ratios}

The most common liquidity ratios are (Table 2):

Table 2. Quick ratio (liquidity grades: 1, 2, and 3)

\begin{tabular}{|c|c|c|c|}
\hline Indicator & Characteristics & $\begin{array}{c}\text { Recommended } \\
\text { value }\end{array}$ & Calculation \\
\hline $\begin{array}{c}\text { Quick liquidity } \\
\text { (Liquidity grade: } 1 . \text { ) }\end{array}$ & $\begin{array}{c}\text { is the ability to repay } \\
\text { short-term liabilities } \\
\text { with the most liquid } \\
\text { resources. }\end{array}$ & $0,2-0,5$ & $\begin{array}{c}\text { Quick ratio = financial } \\
\text { accounts } \\
\text { short- term liabilities } \\
\text { alltogether }\end{array}$ \\
\hline $\begin{array}{c}\text { Current liquidity } \\
\text { (Liquidity grade: 2) }\end{array}$ & $\begin{array}{c}\text { is the ability to repay } \\
\text { current liabilities with } \\
\text { cash equivalents and } \\
\text { receivables }\end{array}$ & $1-1,5$ & $\begin{array}{c}\text { Current liquidity }= \\
\frac{\text { financial accounts }+}{\text { receivables }} \\
\text { short-term liabilities } \\
\text { together }\end{array}$ \\
\hline $\begin{array}{c}\text { Total Liquidity } \\
\text { (Liquidity Grade: } 3 \text { ) }\end{array}$ & $\begin{array}{l}\text { Is The Ability To Settle } \\
\text { Current Liabilities } \\
\text { Through Current Assets }\end{array}$ & $1,8-2,5$ & $\begin{array}{c}\text { Total Liquidity }= \\
\text { Financial Accounts }+ \\
\frac{\text { Receivables }+}{\text { Inventories }} \\
\begin{array}{c}\text { Short-Term Liabilities } \\
\text { Together }\end{array}\end{array}$ \\
\hline
\end{tabular}




\section{ENTREPRENEURSHIP AND SUSTAINABILITY ISSUES}

ISSN 2345-0282 (online) http://jssidoi.org/jesi/ 2021 Volume 9 Number 2 (December) http://doi.org/10.9770/jesi.2021.9.2(16)

\subsection{Analysis of receivables and payables management}

We have solved the research project within several manufacturing companies, but in the mentioned article we numerically list the selected manufacturing company, which is representative of the problems occurring in the field of liquidity and its management in most of them. Based on data from the balance sheets of the selected company for the monitored periods, we prepared an analysis of the company's asset structure (Table 3), where we mainly monitored the distribution of assets in individual components in terms of inclusion of receivables (as part of assets) and liabilities (as part of resources). In the analysis of coverage sources (Table 4), we monitored the structure of own and foreign sources (Table 3).

Table 3. Analysis of the assets of the monitored company

\begin{tabular}{|c|c|c|c|c|c|c|c|c|}
\hline \multirow[b]{2}{*}{ Structure of assets (A) } & \multicolumn{2}{|c|}{2016} & \multicolumn{2}{|c|}{2017} & \multicolumn{2}{|c|}{2018} & \multicolumn{2}{|c|}{2019} \\
\hline & $\begin{array}{c}\text { Value in } \\
\text { EURO } \\
(€) \\
\end{array}$ & $\%$ of $\mathrm{A}$ & $\begin{array}{c}\text { Value in } \\
\text { EURO } \\
(€) \\
\end{array}$ & $\%$ of $\mathrm{A}$ & $\begin{array}{c}\text { Value in } \\
\text { EURO } \\
(€) \\
\end{array}$ & $\%$ of $\mathrm{A}$ & $\begin{array}{c}\text { Value in } \\
\text { EURO } \\
(€) \\
\end{array}$ & $\%$ of $\mathrm{A}$ \\
\hline TOTAL ASSETS & 603885 & 100,00 & 557265 & 100,00 & 568640 & 100,00 & 557355 & 100,00 \\
\hline A. Non-current assets & 291624 & 48,28 & 266776 & 47,87 & 251142 & 44,17 & 251500 & 45,12 \\
\hline $\begin{array}{l}\text { A.I. Long-term } \\
\text { intangible assets, total }\end{array}$ & 0 & 0 & 0 & 0 & 0 & 0 & 0 & 0 \\
\hline $\begin{array}{l}\text { A.II. Long-term } \\
\text { tangible assets, total }\end{array}$ & 291624 & 48,30 & 266776 & 47,87 & 251142 & 44,16 & 251500 & 45,12 \\
\hline A.II.1. Lands & 46429 & 7,68 & 46429 & 8,33 & 46429 & 8,16 & 46429 & 8,33 \\
\hline A.II.2. Buildings & 221643 & 36,70 & 210514 & 37,78 & 199385 & 35,07 & 199385 & 35,77 \\
\hline $\begin{array}{l}\text { A.II. 3. Individual } \\
\text { movables and sets of } \\
\text { movables }\end{array}$ & 23552 & 3,90 & 9833 & 1,76 & 5328 & 0,93 & 5686 & 1,02 \\
\hline $\begin{array}{l}\text { A.III. Long-term } \\
\text { financial assets, total }\end{array}$ & $\mathbf{0}$ & $\mathbf{0}$ & $\mathbf{0}$ & $\mathbf{0}$ & $\mathbf{0}$ & & $\mathbf{0}$ & $\mathbf{0}$ \\
\hline B. Current assets & 312261 & 51,71 & 290489 & 52,13 & 317498 & 55,83 & 305855 & 54,88 \\
\hline B.I. Stocks - total & 91385 & 15,14 & 87531 & 15,71 & 112212 & 19,73 & 130595 & 23,43 \\
\hline B.I.1. Material & 91422 & 15,14 & 87091 & 15,63 & 111355 & 19,58 & 131426 & 23,58 \\
\hline $\begin{array}{l}\text { B.I.2. Advances provided } \\
\text { for inventories }\end{array}$ & -37 & $-0,006$ & 440,00 & 0,08 & 857 & 0,15 & -831 & $-0,15$ \\
\hline $\begin{array}{l}\text { B.II. Long-term } \\
\text { receivables - total }\end{array}$ & 110089 & 18,23 & 102728 & 18,43 & 80000 & 14,07 & 60000 & 10,76 \\
\hline $\begin{array}{l}\text { B.II.1. Receivables from } \\
\text { partners, members and } \\
\text { associations }\end{array}$ & 110089 & 18,23 & 102298 & 18,36 & 80000 & 14,07 & 60000 & 10,76 \\
\hline $\begin{array}{l}\text { B.II.1. Other trade } \\
\text { receivables }\end{array}$ & 0 & 0 & 430,00 & 0,07 & 0 & 0 & 0 & 0 \\
\hline $\begin{array}{l}\text { B.III. Short-term } \\
\text { receivables - total }\end{array}$ & 77309 & 12,80 & 47243 & 8,48 & 54284 & 9,55 & 46777 & 8,39 \\
\hline $\begin{array}{l}\text { B.III.1. Trade receivables } \\
\text { - total }\end{array}$ & 47325 & 7,80 & 47243 & 8,48 & 54284 & 9,55 & 37787 & 6,78 \\
\hline $\begin{array}{l}\text { B.III.1. 1. Other trade } \\
\text { receivables }\end{array}$ & 47325 & 7,80 & 47243 & 8,48 & 54284 & 9,55 & 37787 & 6,78 \\
\hline $\begin{array}{l}\text { B.III.1.2. Tax receivables } \\
\text { and subsidies }\end{array}$ & 29984 & 4,90 & 0 & 0 & 0 & 0 & 8990 & 1,61 \\
\hline $\begin{array}{l}\text { B.IV. Short-term } \\
\text { financial assets - total }\end{array}$ & $\mathbf{0}$ & $\mathbf{0}$ & $\mathbf{0}$ & $\mathbf{0}$ & $\mathbf{0}$ & $\mathbf{0}$ & $\mathbf{0}$ & $\mathbf{0}$ \\
\hline $\begin{array}{l}\text { B.V. Financial accounts } \\
\text { - total }\end{array}$ & 33478 & 5,54 & 52987 & 9,51 & 71002 & 12,49 & 68483 & 12,29 \\
\hline B.V.1. Money & 8445 & 1,39 & 16901 & 3,03 & 43715 & 7,69 & 42780 & 7,68 \\
\hline B.V.2. Bank accounts & 25033 & 4,15 & 36086 & 6,48 & 27287 & 4,80 & 25703 & 4,61 \\
\hline C. Accrurals & $\mathbf{0}$ & $\mathbf{0}$ & $\mathbf{0}$ & $\mathbf{0}$ & $\mathbf{0}$ & $\mathbf{0}$ & $\mathbf{0}$ & $\mathbf{0}$ \\
\hline
\end{tabular}

Source: Own processing based on balance sheets from 2016, 2017, 2018, and 2019. 
The total value of the company's assets fluctuated from 2016 to 2019, while the highest value of assets for the monitored periods of assets was in 2016 and the lowest in 2017, which is a decrease of $7.7 \%$. In 2019, the value of assets was $€ 557,355$, which is also a decrease of $7.7 \%$. The company has fixed assets of which the largest part always consists of tangible assets, particularly land and buildings, ie about $45 \%$. The Company did not and does not have long-term intangible assets, long-term and short-term financial assets at its disposal.

Looking at the structure of assets, it is clear that the majority of current periods are current assets. It is more than $50 \%$ every year. A closer look at current assets revealed that inventories are dominated by material that has fluctuating value over all periods.

Long-term and short-term receivables decreased every year, we will discuss them in more detail in the following sections (Table 4).

Table 4. Analysis of sources of coverage of the company's assets

\begin{tabular}{|c|c|c|c|c|c|c|c|c|}
\hline \multirow{2}{*}{$\begin{array}{c}\text { COVERING } \\
\text { SOURCE } \\
\text { STRUCTURE }(\mathrm{SSt})\end{array}$} & \multicolumn{2}{|c|}{2016} & \multicolumn{2}{|c|}{2017} & \multicolumn{2}{|c|}{2018} & \multicolumn{2}{|c|}{2019} \\
\hline & $\begin{array}{c}\text { Value in } \\
\operatorname{EURO}(€)\end{array}$ & $\begin{array}{l}\% \text { of } \\
\text { SSt }\end{array}$ & $\begin{array}{c}\text { Value in } \\
\text { EURO } \\
(€)\end{array}$ & $\begin{array}{l}\% \text { of } \\
\text { SSt }\end{array}$ & $\begin{array}{c}\text { Value in } \\
\text { EURO } \\
(€) \\
\end{array}$ & $\begin{array}{l}\% \text { of } \\
\text { SSt }\end{array}$ & $\begin{array}{c}\text { Value in } \\
\text { EURO } \\
(€) \\
\end{array}$ & $\begin{array}{l}\% \text { of } \\
\text { SSt }\end{array}$ \\
\hline $\begin{array}{c}\text { TOTA: EQUITY } \\
\text { AND LIABILITIES }\end{array}$ & 603885 & 100,00 & 557265 & 100,00 & 568640 & 100,00 & 557355 & 100,00 \\
\hline A. Equity & 154502 & 25,57 & 169846 & 30,48 & 225749 & 39,70 & 253380 & 45,46 \\
\hline A.I. Basic equity & 6639 & 1,10 & 6639 & 1,19 & 6639 & 1,17 & 6639 & 1,19 \\
\hline A.II. Share premium & 0 & 0 & 0 & 0 & 0 & 0 & 0 & 0 \\
\hline $\begin{array}{l}\text { A.III. Other capital } \\
\text { funds }\end{array}$ & 0 & 0 & 0 & 0 & 0 & 0 & 0 & 0 \\
\hline $\begin{array}{l}\text { A.IV. Statutory reserve } \\
\text { funds }\end{array}$ & 500 & 0,08 & 500 & 0,09 & 500 & 0,09 & 500 & 0,09 \\
\hline $\begin{array}{l}\text { A.IV.1. Statutory } \\
\text { reserve funds and } \\
\text { indivisible fund }\end{array}$ & 500 & 0,08 & 500 & 0,09 & 500 & 0,09 & 500 & 0,09 \\
\hline $\begin{array}{l}\text { A. V. Other funds from } \\
\text { profit }\end{array}$ & 0 & 0 & 0 & 0 & 0 & 0 & 0 & 0 \\
\hline $\begin{array}{l}\text { A.VI. Valuation } \\
\text { differences from } \\
\text { revaluation - total }\end{array}$ & 0 & 0 & 0 & 0 & 0 & 0 & 0 & 0 \\
\hline $\begin{array}{l}\text { A.VII. Profit from } \\
\text { previous years }\end{array}$ & 232908 & 38,56 & 147363 & 26,44 & 162707 & 28,61 & 218610 & 39,22 \\
\hline $\begin{array}{c}\text { A.VII.1. Retained } \\
\text { earnings from previous } \\
\text { years } \\
\end{array}$ & 232908 & 38,56 & 147363 & 26,44 & 162707 & 28,61 & 218610 & 39,22 \\
\hline $\begin{array}{l}\text { A. VIII. Profit for the } \\
\text { period after tax }\end{array}$ & -85545 & $-14,17$ & 15344 & 2,76 & 55903 & 9,83 & 27631 & 4,96 \\
\hline B. Liabilities & 449383 & $\mathbf{7 4 , 4 1}$ & 387419 & 69,52 & 342891 & 60,30 & 303975 & 54,54 \\
\hline $\begin{array}{l}\text { B.I. Long-term } \\
\text { liabilities - total }\end{array}$ & 240 & $\mathbf{0 , 0 4}$ & 72 & $\mathbf{0 , 0 1}$ & 387 & $\mathbf{0 , 0 7}$ & 570 & 0,10 \\
\hline $\begin{array}{c}\text { B.I.1.Trade long-term } \\
\text { liabilities }\end{array}$ & 0 & 0 & 0 & 0 & 0 & 0 & 0 & 0 \\
\hline $\begin{array}{l}\text { B.I.2. Social fund } \\
\text { liabilities }\end{array}$ & 240 & 0,04 & 72 & 0,01 & 387 & 0,07 & 570 & 0,10 \\
\hline $\begin{array}{c}\text { B.II. Long-term } \\
\text { reserves }\end{array}$ & 0 & $\mathbf{0}$ & $\mathbf{0}$ & $\mathbf{0}$ & $\mathbf{0}$ & $\mathbf{0}$ & 0 & $\mathbf{0}$ \\
\hline
\end{tabular}


ENTREPRENEURSHIP AND SUSTAINABILITY ISSUES

ISSN 2345-0282 (online) http://jssidoi.org/jesi/ 2021 Volume 9 Number 2 (December) http://doi.org/10.9770/jesi.2021.9.2(16)

\begin{tabular}{|c|c|c|c|c|c|c|c|c|}
\hline $\begin{array}{c}\text { B.III. Long term } \\
\text { bank loans }\end{array}$ & $\mathbf{2 0 1} \mathbf{6 1 6}$ & $\mathbf{3 3 , 3 8}$ & $\mathbf{1 8 7 5 4 0}$ & $\mathbf{3 3 , 6 5}$ & $\mathbf{1 7 3} \mathbf{4 6 4}$ & $\mathbf{3 0 , 5 1}$ & $\mathbf{1 5 9} \mathbf{3 8 8}$ & $\mathbf{2 8 , 5 9}$ \\
\hline $\begin{array}{c}\text { B.IV. Short-term } \\
\text { liabilities - total }\end{array}$ & $\mathbf{2 4 1 4 5 6}$ & $\mathbf{3 9 , 9 8}$ & $\mathbf{1 9 9} \mathbf{8 0 7}$ & $\mathbf{3 5 , 8 5}$ & $\mathbf{1 6 9 0 4 0}$ & $\mathbf{2 9 , 7 2}$ & $\mathbf{1 4 4} \mathbf{0 1 7}$ & $\mathbf{2 5 , 8 4}$ \\
\hline $\begin{array}{c}\text { B.IV.1. Trade payables } \\
\text { - total }\end{array}$ & 226066 & 37,43 & 180701 & 32,43 & 146110 & 25,69 & 131697 & 23,63 \\
\hline $\begin{array}{c}\text { B.IV.2. Other trade } \\
\text { payables }\end{array}$ & 226066 & 37,43 & 180701 & 32,43 & 146110 & 25,69 & 131697 & 23,63 \\
\hline $\begin{array}{c}\text { B.IV.3. Payables to } \\
\text { partners and } \\
\text { associations }\end{array}$ & 0 & & & & & & & \\
\hline $\begin{array}{c}\text { B.IV.4. Payables to } \\
\text { employees }\end{array}$ & 7035 & 1,16 & 5001 & 0,90 & 5873 & 1,03 & 4756 & 0,86 \\
\hline $\begin{array}{c}\text { B.IV.5. Social security } \\
\text { liabilities }\end{array}$ & 3931 & 0,65 & 3166 & 0,56 & 3515 & 0,62 & 2868 & 0,51 \\
\hline $\begin{array}{c}\text { B.IV.6. Tax liabilities } \\
\text { and subsidies }\end{array}$ & 903 & 0,14 & 10833 & 1,94 & 13255 & 2,33 & 4409 & 0,79 \\
\hline $\begin{array}{c}\text { B.IV.7. Other } \\
\text { liabilities }\end{array}$ & 3521 & 0,57 & 106 & 0,02 & 0 & 0,05 & 287 & 0,05 \\
\hline $\begin{array}{c}\text { B.V. Short- term } \\
\text { reserves }\end{array}$ & $\mathbf{0}$ & $\mathbf{0}$ & $\mathbf{0}$ & $\mathbf{0}$ & $\mathbf{0}$ & $\mathbf{0}$ & $\mathbf{0}$ & $\mathbf{0}$ \\
\hline $\begin{array}{c}\text { B.VI. Current bank } \\
\text { loans }\end{array}$ & $\mathbf{6 0 7 1}$ & $\mathbf{1 , 0 0 5}$ & $\mathbf{0}$ & $\mathbf{0}$ & $\mathbf{0}$ & $\mathbf{0}$ & $\mathbf{0}$ & $\mathbf{0}$ \\
\hline $\begin{array}{c}\text { B.VII. Short- term } \\
\text { financial assistance }\end{array}$ & $\mathbf{0}$ & $\mathbf{0}$ & $\mathbf{0}$ & $\mathbf{0}$ & $\mathbf{0}$ & $\mathbf{0}$ & $\mathbf{0}$ & $\mathbf{0}$ \\
\hline \begin{tabular}{c} 
C. Accruals \\
\hline
\end{tabular} & $\mathbf{0}$ & $\mathbf{0}$ & $\mathbf{0}$ & $\mathbf{0}$ & $\mathbf{0}$ & $\mathbf{0}$ & $\mathbf{0}$ & $\mathbf{0}$ \\
\hline
\end{tabular}

Source: Own processing based on balance sheets from 2016, 2017, 2018, and 2019.

Looking at the sources of coverage, we found that the greater part consists of liabilities, on average $64.6 \%$ of total sources of coverage each year, and a smaller part is equity on average 35.3\% each year. In the structure of sources of coverage for all monitored periods, equity has a different amount, which has an increasing tendency. It forms a smaller part of the total sources of coverage. While in 2016 the value of equity amounted to $€ 154,502$, in the last monitored year 2019 its value increased by up to $64 \%$, to a value of $€ 253,380$.

From external sources, the amount of liabilities decreased overall during the period under review. The highest share of liabilities was represented by short-term liabilities on average $32.8 \%$ and long-term bank loans, which accounted for an average of $31.5 \%$ of liabilities.

In this part of the practical analysis of receivables, we discuss the development and management of long-term and short-term receivables of the company, which are important for the financial stability of the company. We follow the last four accounting periods, ie years 2016 - 2019. We also describe the methods of recovery of the company's receivables. The basis for this analysis is mainly statements from financial statements.

\subsection{Receivables analysis}

The clear status and structure of monitored long-term receivables are shown in Table 5, in which we analyze and compare individual accounting periods using indexing (Table 5). 
Table 5. Status and structure of long - term receivables

\begin{tabular}{|c|c|c|c|c|c|c|c|c|}
\hline & \multicolumn{4}{|c|}{ Value in EURO (€) } & \multicolumn{4}{|c|}{ Index } \\
\hline & 2016 & 2017 & 2018 & 2019 & $\begin{array}{c}2017 / \\
2016\end{array}$ & $\begin{array}{c}2018 / \\
2017\end{array}$ & $\begin{array}{c}2019 / \\
2018\end{array}$ & $\begin{array}{l}2019 / \\
2016\end{array}$ \\
\hline $\begin{array}{l}\text { Long-term } \\
\text { receivables from } \\
\text { partners, members } \\
\text { and associations }\end{array}$ & 110089 & 102298 & 80000 & 60000 & 0,93 & 0,78 & 0,75 & 0,54 \\
\hline $\begin{array}{l}\text { Other trade } \\
\text { receivables }\end{array}$ & 0 & 430 & 0 & 0 & 0 & 0 & 0 & 0 \\
\hline $\begin{array}{l}\text { Long-term } \\
\text { receivables - total }\end{array}$ & 110089 & 102728 & 80000 & 60000 & 0,93 & $\mathbf{0 , 7 8}$ & 0,75 & 0,54 \\
\hline
\end{tabular}

Source: Own processing based on the company's financial statements from 2016 - 2019.

The sum of the company's long-term receivables for all periods consists of long-term receivables from partners, members, and associations, and other trade receivables. The highest value of long-term receivables, ie $€ 110,089$, the company reached in 2016, which accounted for $18.23 \%$ of the company's total assets. The lowest value of long-term receivables was achieved by the company in 2019 , t. j. $€ 60,000$, which represents $10.76 \%$ of the total assets in a given year. Of the total long-term receivables, they always accounted for the highest value of receivables from partners, members, and associations. The value of the company's total long-term receivables from 2016 to 2019 had a declining trend.

The clear status and structure of monitored short-term receivables are shown in Table 6, in which we analyze and also compare individual accounting periods using indexing (Table 6).

Table 6. Status and structure of short-term receivables

\begin{tabular}{|c|c|c|c|c|c|c|c|c|}
\hline & \multicolumn{4}{|c|}{ Value in EURO (€) } & \multicolumn{3}{c|}{ Index } \\
\cline { 2 - 10 } & $\mathbf{2 0 1 6}$ & $\mathbf{2 0 1 7}$ & $\mathbf{2 0 1 8}$ & $\mathbf{2 0 1 9}$ & $\begin{array}{c}\mathbf{2 0 1 7 /} \\
\mathbf{2 0 1 6}\end{array}$ & $\begin{array}{c}\mathbf{2 0 1 8 /} \\
\mathbf{2 0 1 7}\end{array}$ & $\begin{array}{c}\mathbf{2 0 1 9 /} \\
\mathbf{2 0 1 8}\end{array}$ & $\begin{array}{c}\mathbf{2 0 1 9 /} \\
\mathbf{2 0 1 6}\end{array}$ \\
\hline $\begin{array}{c}\text { Other trade } \\
\text { receivables }\end{array}$ & 47325 & 47243 & 54284 & 37787 & 0,99 & 1,15 & 0,69 & 0,79 \\
\hline $\begin{array}{c}\text { Tax receivables and } \\
\text { subsidies }\end{array}$ & 29984 & 0 & 0 & 8990 & 0 & 0 & 0 & 0,29 \\
\hline $\begin{array}{c}\text { Short-term } \\
\text { receivables - total }\end{array}$ & $\mathbf{7 7 3 0 9}$ & $\mathbf{4 7 3 4 3}$ & $\mathbf{5 4 2 8 4}$ & $\mathbf{4 6 ~ 7 7 7}$ & $\mathbf{0 , 6 1}$ & $\mathbf{1 , 1 5}$ & $\mathbf{0 , 8 6}$ & $\mathbf{0 , 6 1}$ \\
\hline
\end{tabular}

Source: Own processing based on the company's financial statements from 2016 - 2019.

For long-term receivables, we can see that they are still due. For the company, this means that debtors pay these receivables on time.

For short-term receivables, we see that they are not paid on time, most of the short-term receivables are paid overdue. This means for the company that the debtors do not meet the set payment deadlines and most of them pay after the due date. 
If the receivables are not paid at all, the company must proceed to the recovery of these receivables. Also, in order to avoid incurring bad debts, it is the company's duty to create measures and devise ways of resolving these debts. And that already falls, de facto, into their management.

Methods of debt collection are possible:

1. telephone recovery - the company's economist contacts the debtor via the telephone line about the unpaid receivable, informs him about the fact that follows from it, and then listens to the feedback from the debtor, writes it down, and agrees with the debtor that immediately after the interview forwards a copy of the invoice and a list of outstanding items to the e-mail box. The aim is not to scare the debtor, but to achieve at least the promise of payment.

2. written recovery - the company's economist will send the debtor a written reminder defining the outstanding claim, also informing that there will be a suspension of supplies or withdrawal from the contract if the debtor does not pay the claim. The first reminder is sent only slightly by the company so that the debtor knows and does not forget that the claim needs to be paid. Only after the third written claim is the company willing to proceed to judicial enforcement

\subsection{Liabilities analysis}

In the analysis of liabilities, we will focus on determining the value and development of long-term and short-term liabilities of the company and also compare them with the use of indexing (Table 7).

Table 7. Structure of long-term liabilities

\begin{tabular}{|c|c|c|c|c|c|c|c|c|}
\hline & \multicolumn{4}{|c|}{ Value in EURO (€) } & \multicolumn{4}{|l|}{ Index } \\
\hline & 2016 & 2017 & 2018 & 2019 & \begin{tabular}{|l|}
$2017 /$ \\
2016 \\
\end{tabular} & \begin{tabular}{|l|}
$2018 /$ \\
2017 \\
\end{tabular} & \begin{tabular}{|l|}
$2019 /$ \\
2018 \\
\end{tabular} & \begin{tabular}{|l|}
$2019 /$ \\
2016 \\
\end{tabular} \\
\hline $\begin{array}{l}\text { Long-term } \\
\text { trade payables }\end{array}$ & 0 & 0 & 0 & 0 & 0 & 0 & 0 & 0 \\
\hline $\begin{array}{l}\text { Social fund } \\
\text { liabilities }\end{array}$ & 240 & 72 & 387 & 570 & 0,3 & 5,38 & 1,47 & 2,37 \\
\hline $\begin{array}{l}\text { Long-term } \\
\text { liabilities - total }\end{array}$ & 240 & 72 & 387 & 570 & 0,3 & 5,38 & 1,47 & 2,37 \\
\hline $\begin{array}{l}\text { Long-term } \\
\text { reserves }\end{array}$ & 0 & 0 & 0 & 0 & 0 & 0 & 0 & 0 \\
\hline $\begin{array}{l}\text { Long-term bank } \\
\text { loans }\end{array}$ & 201616 & 187540 & 173464 & 159388 & 0,93 & 0,92 & 0,91 & 0,79 \\
\hline
\end{tabular}

Source: Own processing based on the financial statements from the years 2016-2019.

The structure of the company's long-term liabilities consists of long-term bank loans and liabilities from the social fund (Table 8). 
Table 8. Structure of current liabilities

\begin{tabular}{|c|c|c|c|c|c|c|c|c|}
\hline & \multicolumn{4}{|c|}{ Value in EURO (€) } & \multicolumn{4}{|c|}{ Index } \\
\hline & 2016 & 2017 & 2018 & 2019 & $\begin{array}{l}2017 / \\
2016 \\
\end{array}$ & $\begin{array}{l}2018 / \\
2017 \\
\end{array}$ & $\begin{array}{l}2019 / \\
2018 \\
\end{array}$ & $\begin{array}{l}2019 / \\
2016 \\
\end{array}$ \\
\hline Trade payables & 226066 & 180701 & 146110 & 131697 & 0,8 & 8,81 & 0,9 & 0,58 \\
\hline $\begin{array}{l}\text { Payables to } \\
\text { partners and } \\
\text { associations }\end{array}$ & 0 & 0 & 287 & 287 & 0 & 0 & 1 & 0 \\
\hline $\begin{array}{c}\text { Payables to } \\
\text { employees }\end{array}$ & 7035 & 5001 & 5873 & 4756 & 0,71 & 1,17 & 0,81 & 0,67 \\
\hline $\begin{array}{c}\text { Social security } \\
\text { liabilities }\end{array}$ & 3931 & 3166 & 3515 & 2868 & 0,81 & 1,11 & 0,82 & 0,72 \\
\hline $\begin{array}{l}\text { Tax liabilities } \\
\text { and subsidies }\end{array}$ & 903 & 10833 & 13255 & 4409 & 11,99 & 1,22 & 0,33 & 4,88 \\
\hline Other liabilities & 3521 & 106 & 0 & 0 & 0,03 & 0 & 0 & 0 \\
\hline $\begin{array}{c}\text { Short-term } \\
\text { liabilities - total }\end{array}$ & 241456 & 199807 & 169040 & 144017 & $\mathbf{0 , 8 3}$ & 0,85 & $\mathbf{0 , 8 5}$ & 0,60 \\
\hline $\begin{array}{c}\text { Short-term } \\
\text { reserves }\end{array}$ & 0 & 0 & 0 & 0 & 0 & 0 & 0 & 0 \\
\hline $\begin{array}{c}\text { Current bank } \\
\text { loans }\end{array}$ & 6071 & 0 & 0 & 0 & 0 & 0 & 0 & 0 \\
\hline $\begin{array}{c}\text { Short-term } \\
\text { financial } \\
\text { assistance }\end{array}$ & 0 & 0 & 0 & 0 & 0 & 0 & 0 & 0 \\
\hline
\end{tabular}

Source: Own processing based on data from financial statements 2016-2019.

The structure of short-term liabilities for all monitored periods consists of trade payables, payables to partners and associations, payables to employees, payables from social insurance, tax liabilities and subsidies, and other payables. Short-term liabilities also include short-term reserves, current bank loans, and short-term financial assistance. The largest part of liabilities consisted of trade payables, with the highest value in 2016, which accounted for $37.43 \%$ of the total sources of coverage. They had the lowest value in 2019, which represented $23.63 \%$ of the total sources of coverage. The company reported current bank loans only in 2016. The company did not have short-term reserves or short-term financial assistance.

The company's total short-term liabilities were declining, meaning that the company gradually repaid them.

\subsection{Liquidity analysis}

In this part of the analysis, we will focus on the solvency of the company. We will examine whether the company has sufficient liquidity, ie whether it can turn assets into money, with which it is then able to pay its liabilities. We selected ratios for liquidity analysis (Table 9). 
Table 9. Result values - Ready liquidity (Level 1 liquidity)

\begin{tabular}{|c|c|c|c|c|}
\hline Observed period & $\mathbf{2 0 1 6}$ & $\mathbf{2 0 1 7}$ & $\mathbf{2 0 1 8}$ & $\mathbf{2 0 1 9}$ \\
\hline Value & 0,13 & 0,27 & 0,42 & 0,47 \\
\hline
\end{tabular}

Source: Own processing based on formulas and data from balance sheets from 2016-2019.

When calculating available liquidity, we put the ratio of financial accounts to short-term liabilities in total. Their value ranges from 0.2 to 0.5 . This liquidity represents the narrowest view of current solvency at a given date and is used for day-to-day financial management. It is considered safe when at least 0.20 cents of the most liquid funds per 1 euro of commitments. The values of the ready liquidity of this company improved in the monitored period from year to year (2016 - 2019).

Based on our calculations, the value of ready liquidity in 2016 was 0.13 , which did not even reach the recommended level and is therefore considered insufficient. In 2017, its value was 0.27 , which represented an improvement compared to 2016, and an increase also occurred in 2018 to 0.42 . ensuring ready liquidity. The highest value was in the last monitored year 2019, t. j. 0.47 , which in this case meant that the company had sufficient secured liquidity. These calculations show us that the company should focus on increasing this indicator in order to be able to face short-term financial outages or other performance (Table 10).

\begin{tabular}{l} 
Table 10. Result values - Current liquidity (Level 2 liquidity) \\
\begin{tabular}{|c|c|c|c|c|}
\hline Observed period & $\mathbf{2 0 1 6}$ & $\mathbf{2 0 1 7}$ & $\mathbf{2 0 1 8}$ & $\mathbf{2 0 1 9}$ \\
\hline Value & 0,91 & 1,02 & 1,21 & 1,21 \\
\hline
\end{tabular} \\
\hline
\end{tabular}

Within current liquidity, we put into ratio financial accounts with short-term receivables to total short-term liabilities. The value of this indicator is 1-1.5. This indicator expresses the company's ability to cover current needs and debts with cash and receivables. Based on the calculations, the value of current liquidity in 2016 was 0.91, which means that it did not even reach the recommended level. In the following year 2017, the company reported a value of 1.02, which means a slight improvement in this indicator compared to 2016.

In 2018 and 2019 it reached the same level t. j. 1.21, which meant that the company secured regular liquidity to a sufficient extent. However, overall we see an improvement for all monitored periods, but even so, this indicator should improve so that the company is more prepared for possible financial fluctuations (Table 11).

Table 11. Result values - Total liquidity (Level 3 liquidity)

\begin{tabular}{|c|c|c|c|c|}
\hline Observed period & $\mathbf{2 0 1 6}$ & $\mathbf{2 0 1 7}$ & $\mathbf{2 0 1 8}$ & $\mathbf{2 0 1 9}$ \\
\hline Value & 1,30 & 1,45 & 1,8 & 2,12 \\
\hline
\end{tabular}

Source: Own processing based on formulas and data from balance sheets from 2016-2019.

With total liquidity, we put into ratio financial accounts with receivables and inventories to short-term liabilities together. The value of this indicator ranges from 1.8 to 2.5. This indicator is used for long-term evaluation of the development of the company's solvency.

In 2016, the value of 1.30 was reported in our calculations of total liquidity, which means that the company did not reach even the recommended value, it was also in the following year 2017, where it reached a value only slightly higher, i.e. 1.45. This indicates a lack of overall liquidity. However, in the following years, its values improved. In 2018, the value reached the level of 1.8, which means that the company's solvency improved, and in 
the last monitored year 2019, the company had the best value of i.e. 2.12, which is a prerequisite for improving overall solvency in the future.

The values of ready, current, and total liquidity were at a safe level only in the last monitored years 2018 and 2019. They could be considered safe when their value was at the recommended level.

\section{Final evaluation and recommendations}

Within the research project, based on the performed analysis, we found the following facts:

1 / In all monitored periods, the company reported the predominant amount of total liabilities over receivables.

To improve the situation in the company, we have proposed several framework solutions:

- reassessment of the company's production structure (to produce more efficiently)

- workforce optimization,

- optimization and setting up trading (searching for new opportunities and customers)

- creation of reserves.

With these changes, in addition to reducing production costs and streamlining production as a whole, we will also shorten the time between production and sales of the product, which will have an impact on the overall reduction of payables.

2 / In the area of receivables and liabilities management:

From the analysis, we found that the company has many short-term receivables, in which the debtors paid their receivables only after the real maturity. The company could approach the following solutions:

- prevention of bad debts, search for new customers,

- verification of customers, which means closer verification of their financial situation,

- adjustment of receivables due dates,

- better communication and re-meetings with debtors,

- the pre-determined specific performance of claims and the precise conditions for performance,

- benefits for customers for early payment of invoices,

- penalties for non-compliance with due dates,

- receivables insurance.

The company should always strive to get its customers to pay their debts on time. It should take precautionary measures to prevent late or bad debts, thereby not focusing on their recovery and also choosing appropriate methods to apply and lead customers to meet their obligations.

3 / In the area of liquidity

Based on the calculations of ratios, we found insufficient liquidity. This problem can be solved as the condition has gradually improved. We have proposed the following solutions:

- sale of unnecessary stocks and monetizable means of production,

- reduction of liabilities, increase of receivables, ie plan of their management 


\section{ENTREPRENEURSHIP AND SUSTAINABILITY ISSUES}

ISSN 2345-0282 (online) http://jssidoi.org/jesi/

2021 Volume 9 Number 2 (December)

http://doi.org/10.9770/jesi.2021.9.2(16)

- get rid of loans,

- check the condition of the rolling stock and the costs incurred annually for its operation,

- develop a cash flow management plan in the company.

In order to achieve a better level of liquidity, we mainly recommend companies reduce liabilities and increase receivables. As mentioned above, shorten the maturities of receivables (revenue invoices) and increase the maturities of liabilities (cost invoices). For short-term receivables, the company should focus on increasing shortterm financial assets that have very high liquidity. This applies mainly to cash (the company had a higher amount every year), money in accounts (the company has enough), but we would also recommend securities that can be sold at any time. The risk is that the company has a larger amount of loans from banks. The best recommendation is to re-evaluate all loans. The company's operating costs have a significant impact on liquidity. We recommend performing an in-depth analysis of the company's operating costs in order to find a solution to reduce them and thus reduce the company's liquidity requirements

In conclusion, liquidity as an important element in the organization depends on many factors, but consistent management of receivables and liabilities and also time management can keep it at the required level necessary for the successful operation of the organization and ensure the financial stability of the company.

\section{References}

Alex, J. (2005). Financial and economic analysis. Bratislava: IRIS, 121 p. ISBN 80-89018-90-4.

Bernstein, L.A. \& Wild, J.J. (1999). Analysis of Financial Statement. New York: Irwin McGraw - Hill, ISBN 0-07-094504-7

Daniel, P. (2013). Management and recovery of receivables. Bratislava: Iura Edition, Spol, 472 p. ISBN ePub 978-80-8078-679-3.

Farkaš, R. (2020). Financial statement of trading companies, Bratislava: Wolters Kluwer, ISBN 978-80-571-0247-2

Fabus, M. (2015). Impact of foreign direct investment on unemployment development in selected regions of Slovak Republic. Economic Annals XXI, 19(155), 63-66. http://soskin.info/userfiles/file/Economic-Annals-pdf/S155-0014(14)063.pdf

Frintrup, M., Schmidthuber, L. \& Hilgers, D. (2020). Towards accounting harmonization in Europe: a multinational survey among budget experts. International Review of Administrative Sciences, Article Number 0020852320915640

http://doi.org/10.1177/0020852320915640

Gernon, H.M. \& Meek, G.K. (2001). Accounting - An International Perspective. 5th ed. New York: Irwin/McGraw-Hill, ISBN-13: 9780072316384

Horváthová, J., MokriŠová, M. \& Suhányiová, A. (2016). Financial controlling for managers. Prešov: Bookman, 218 p. ISBN 978-808165-151-9.

Hellmann, A. \& Patel, C. (2021). Translation of International Financial Reporting Standards and implications for judgments and decisionmaking. Journal of Behavioral and Experimental Finance, 30, Article Number100479 http://doi.org/10.1016/j.jbef.2021.100479

Henrique, Marcelo Rabelo; da Silva, Jessica Medeiros; Saporito, Antonio; et al. (2020). Tax accounting: bibliometric study of the accounting area between the period 2010 to 2020. Revista Contabilidade E Controladoria-Rc C, 12(3), 148-164.

Hillebrandt, M. \& Leino-Sandberg, P. (2021). Administrative and judicial oversight of trilogies. Journal of European Public Policy, 28(1), 53-71. https://doi.org/10.1080/13501763.2020.1859598 


\section{ENTREPRENEURSHIP AND SUSTAINABILITY ISSUES}

ISSN 2345-0282 (online) http://jssidoi.org/jesi/ 2021 Volume 9 Number 2 (December)

http://doi.org/10.9770/jesi.2021.9.2(16)

Jakubec, M. \& Kardoš, P. (2016). Business value management. Bratislava: Wolters Kluwer, 284 p. ISBN 978-80-8168-460-9.

Jenčová, S. \& Rákoš, J. (2010). Financial and economic analysis and financial planning. Prešov: Prešovská univerzita v Prešove, Faculty of Management, 286 p. ISBN 978-80-555-0186-4.

Kainth, A. \& Wahlstrom, RR. (2021). Do IFRS Promote Transparency? Evidence from the Bankruptcy Prediction of Privately Held Swedish and Norwegian Companies. Journal of Risk and Financial Management, 14(3), Article Number123 http://doi.org/10.3390/jrfm14030123

Kajanová, J., Ölvecká, V. \& Saxunová, D. (2014). Evaluation of property and capital structure. Praha: Wolters Kluwer, 88 p.

Kajanová, J. (2014), Analysis of the development of the tax system of the Slovak Republic after the accession to the European Union In: Slovakia - Plzeň: Aleš Čeněk, p. 64-78. ISBN 978-80-7380-520-3

Kieso, D.E. \& Weygandt, J.J. (2007). Intermediate Accounting. Hoboken, NJ : Wiley. ISBN 978-0-470-12 874-9

Kotulič, R., Király, P. \& Rajčániová, M. (2018). Financial analysis of the company. Third edition. Bratislava: Wolters Kluwer SR, 232 p. ISBN 978-80-8168-888-1.

Lombardi, R., Schimperna, F., Smarra, M. \& Sorrentino, M. (2020). Accounting For Infrastructure Assets in the Public Sector: The State of the Art in Academic Research and International Standards Setting. Public Money \& Management, 41(3), 203-212.

http://doi.org/10.1080/09540962.2020.1840761

Majduchová, H. \& Neumannová, A. (2008). Business management for managers. Bratislava: Iura Edition. ISBN: 978-80-8078-200-9

Majduchová, H. et al. (2020). Business management. Bratislava: Wolters Kluwer SR, 424 p. ISBN 978-80-571-0272-4.

Mládek, R. (2005). World accounting. IFRS. US-GAAP. Praha: Linde, ISBN 80-7201-519-2

Miah, MS., Jiang, HY., Rahman, A. \& Stent, W. (2021). The impact of IFRS complexity on analyst forecast properties: The moderating role of high quality audit. International Journal of Finance \& Economics http://doi.org/10.1002/ijfe.2456 JAN 2021 Early Access

Miah, MS. (2021). Does IFRS convergence bring improvement in firm performance? An empirical analysis. Journal of Chinese Economic and Business Studies, 19(1), 95-107. http://doi.org/10.1080/14765284.2020.1846010

Natalizi, D. (2020). Public sector accounting contexts in the EPSAS change: a comparative study of Italy and Sweden. International Review of Administrative Sciences 0020852319894680 http://doi.org/10.1177/0020852319894680

Oreský, M. \& Rehák, R. (2019). Financial and economic analysis of a gusiness enterprise. Bratislava: Wolters Kluwer, ISBN: 978-80571-0174-1

Pavic, I. (2020). Analysis of Changes in International Financial Reporting Standards and its Effects on Comparability and Consistency of Financial Statements. Ekonomski Pregled, 71(4), 331-357. http://doi.org/10.32910/ep.71.4.2

Roca, F. (2021). The influence of mandatory adoption of IFRS in Argentina on value relevance of accounting information. Journal of Applied Economics, 24(1), 154-172. http://doi.org/10.1080/15140326.2021.1900695

Riahi-Belkaoui, A. (2000). Accounting Theory, Business Press, ISBN 9781861525208

Suhányiová, A. \& Fabian, Š. (2010). Double-entry bookkeeping of business entities in the theory and practice of an accountant and a financial manager. Prešov: University of Prešov, in Prešov, Faculty of Management, 421 p. ISBN 978-80-555-0278-6.

Savina, N., Pozniakovska, N. \& Miklukha, O. (2021). Conceptual Framework For Financial Reporting: Integrated Policy. Financial and Credit Activity-Problems of Theory and Practice. 1(36), 76-83. ISSN 2306-4994, ISSN 2310-8770 WOS:000645131200008 


\section{ENTREPRENEURSHIP AND SUSTAINABILITY ISSUES}

ISSN 2345-0282 (online) http://jssidoi.org/jesi/

2021 Volume 9 Number 2 (December)

http://doi.org/10.9770/jesi.2021.9.2(16)

Sacer, I.M., \& Zyznarska-Dworczak, B. (2020). Assets Measurement Principles According to Croatian and Polish Accounting Standards. Croatian Economic Survey, 22(1), 41-64 http://doi.org/10.15179/ces.22.1.2

Silva, A., Jorge, S. \& Rodrigues, LL. (2021a). Enforcement and accounting quality in the context of IFRS: is there a gap in the literature? International Journal of Accounting and Information Management http://doi.org/10.1108/IJAIM-08-2020-0126 JAN 2021 Early Access

Silva, AP., Fontes, A. \& Martins, A. (2021b). Longitudinal Perceptions of Enforcement Mechanisms in an Ifrs-Based Accounting Reform. Polish Journal of Management Studies, 23(2), 495-511 http://doi.org/10.17512/pjms.2021.23.2.30

Stewart, E., \& Connolly, C. (2021). Recent UK Central Government Accounting Reforms: Claimed Benefits and Experienced Outcomes. ABACUS. A Journal of Accounting Finance and Business Studies, 57(3), 557-592. http://doi.org/10.1111/abac.12222

Suhányiová, A., Korečko, J. \& Mokrišová, M. (2016). Postupy v podvojnom účtovníctve podnikatel’ov (Procedures in double-entry accounting of entrepreneurs). Prešov: Bookman, 223 p. ISBN 978-80-8165-215-8.

Suhányiová, A. (2009). Analytical view of accounting as a source of information in management. Prešov: University of Prešov, in Prešov, Faculty of Management, 192 p. ISBN 978-80-8068-956-8.

Suhányiová, A. (2011). Introduction to double entry accounting for financial managers. Prešov: University of Prešov, in Prešov, Faculty of Management, 153 p. ISBN 978-80-555-0333-2.

Šlosárová, A. \& Blahušiaková, M. (2020). Analysis of financial statements. Bratislava: Wolters Kluwer SR, 440 p. ISBN 978-80-571-01666.

Štangová, N. \& Hajduchová, E. (2010). Accounting. Bratislava, 198 p. ISBN978-80-970495-5-3.

Štangová, N., Víghová, A. Hajduchová, E. (2012). Accounting in the context of public administration and small and medium - sized enterprises. Trenčín: Inštitút aplikovaného manažmentu, 439 p. ISBN 978-80-970802-9-7.

Šuranová, Z. \& Škoda, M. (2007). International accounting. Banská Bytrica: Faculty of Economics UMB, ISBN 978-80-8083-4388

Tawiah, V. \& Gyapong, E. (2021). International financial reporting standards, domestic debt finance and institutional quality: Evidence from developing countries. International Journal of Finance \& Economics http://doi.org/10.1002/ijfe.2575 MAY 2021 Early Access

Tumpach, M. (2006). International Standards for the Preparation of Financial Statements, IFSR/IAS. Bratislava: Iura Edition, ISBN 808078-072-2

Vlachynský, K. et al. (2009). Corporate Finance. Bratislava: Iura Edition, 524 p. ISBN 978-80-8078-258-0.

Wijekoon, N., Samkin, G, \& Sharma, U. (2021). International financial reporting standards for small and medium-sized entities: a new institutional sociology perspective. Meditari Accountancy Research http://doi.org/10.1108/MEDAR-06-2020-0929 JUN 2102 Early Access

Zalai, K. (2016). Financial and economic analysis of the company. Bratislava: Sprint. ISBN 978-80-89710-22-5 


\section{ENTREPRENEURSHIP AND SUSTAINABILITY ISSUES}

ISSN 2345-0282 (online) http://jssidoi.org/jesi/

2021 Volume 9 Number 2 (December)

http://doi.org/10.9770/jesi.2021.9.2(16)

\section{Acknowledgments}

The paper is the output of a scientific project IGA no. 1/2021 "Modernizing the Business Areas in European Countries in the Current Challenges with the Aim of Ensure Sustainable Economic Growth" (Funder: VSEMvs IGA VSEMvs, i.e. School of Economics and Management in Public Administration).

Prof. Ing. Nora ŠTANGOVÁ, CSc. is head of the University of Economics and Management of Public Administration in Bratislava, Department of Small and Medium Business, in Bratislava (Slovak Republic). Scientific field: Accounting, Public Administration ORCID ID: https://orcid.org/0000-0002-9787-6169

PhDr. Agneša VÍGHOVÁ, PhD. is head of the University of Economics and Management of Public Administration in Bratislava, Department of public administration, in Bratislava (Slovak Republic). Scientific field: Accounting, Taxation, Statutory audit ORCID ID: $\underline{\text { https://orcid.org/0000-0001-8094-0067 }}$

Copyright (C) 2021 by author(s) and VsI Entrepreneurship and Sustainability Center This work is licensed under the Creative Commons Attribution International License (CC BY). http://creativecommons.org/licenses/by/4.0/

c) (i) Open Access 